\title{
Model of Teaching English at Architectural University
}

\author{
Olga Kozlova*, Tatyana Astafurova, and Natalya Vishnevetskaya \\ ${ }^{1}$ Volgagrad State Technical University, Institute of Architecture and Civil Engineering, 400005, 28 Lenina St., Volgograd, Russia
}

\begin{abstract}
Recent research shows that teaching English in architectural universities has specific features in terms of vocabulary, grammar and other aspects. The purpose of this article is to present the three-stage model of teaching English to students of architectural and building specialities. The description of the highlighted stages of the suggested model enables future specialists to master their knowledge of English and apply it in their professional sphere.
\end{abstract}

Nowadays the foreign communicative competence is a dominating factor in teaching a foreign language. The English language is the function of communication, education and is also an instrument of collaboration and interaction in modern architectural society. Most students are interested in the practical use of the English language not only as a means of introduction to the world culture or ability to travel, communicate with foreigners, but also as an efficient and necessary tool in order to be competent in the labour market and as a result to become a highly qualified specialist. In modern architectural environment, employees are expected to possess professional skills to be able to compete internationally. It also depends on the language skills of specialists even if their future activities are not closely connected with the linguistic field.

Explorers have different approaches to the solution of the problem of teaching English in architectural universities. Generally speaking, foreign communicative competence is considered as the main aspect of teaching a foreign language. The structure of the communicative competence has been described in a wide range of publications. Lately, the following components of communicative competence are determined: language competence that is the knowledge of vocabulary and grammar; sociolinguistic competence connected with the ability to react appropriately in different cultural and social situations applying adequate language means in accordance with the aim and type of communicative situations, the social roles of participants; discourse competence, which is the ability to understand the utterances of different communicative types, to form linked and logical sentences in different functional styles; strategic competence that means being aware of verbal and nonverbal means and strategies applied to achieve the target; sociocultural competence that means knowledge of cultural peculiarities of customs, traditions, behavioral norms of native speakers, and the ability to understand and adequately use them in a different culture; social competence as the ability and self-confidence in communication with people of different layers $[1,2,3,10]$.

A foreign language is a compulsory subject in the architectural university. The curriculum of teaching is based on the knowledge and the skills obtained by students at schools. By the end of their study, students have to possess the skills of everyday communication, understand monological and dialogical speech on general, cultural and professional topics; acquire the basic grammar material and be able to use the necessary grammatical phenomena, know essential vocabulary used in everyday and professional communication; read and understand literature on general and special topics with a dictionary; develop the skills of oral and written speech; make reports; take part in discussions on general, cultural and professional topics; master basic writing skills in everyday and professional correspondence; have basic skills of translating literature on general and professional topics $[4,7,8]$.

Teaching English at the architectural university has some peculiarities and the teacher of English faces the following problems:

- an academic group includes students demonstrating different levels of language skills;

- groups may include beginners, intermediate and advanced learners;

- foreign language is not a basic necessity for students in their future occupation;

- formation of groups based on the students' language skills level is rarely possible.

This requires an individual approach to each student within the group work. This is complicated by the fact that students have to acquire not only the language for general purposes (LGP), but also the language for special purposes (LSP). Learning terms require background knowledge and because a foreign language at the architectural university is studied during the first two years, most students are not familiar with the system of special concepts and terms of their future profession in Russian. Thus, the teacher of a foreign language has to introduce and develop interdisciplinary links with

* Corresponding author: kornienko_o@list.ru 
professional subjects delivered in Russian within the architectural university curriculum $[6,9]$.

This leaves an imprint on the model of teaching English which is characterized by its specific content, modules and methods. What should an architect or a builder know to be able to exist in modern architectural foreign environment? What language skills should be developed to create his professional activity in modern conditions of globalization? In what order should the material be introduced and consolidated?

The content aspect of the English teaching model includes basic specific concepts and terms, represented in the following classification:

1. Architectural and building terms (e.g. a roof, stanchion, bearing wall, excavation, shallow foundation, drilled hole, bench mark, etc.).

2. Verbs associated with position (e.g. to face, be bounded, be located, be situated, etc.).

3. Adverbs, prepositions and prepositional phrases expressing position (e.g. perpendicular to, at right angles to, parallel, beyond, on the right, on the left of, behind, in front of, etc.).

4. Verbs and their combinations, adjectives describing purposes (e.g. to function, serve, be used for, provide, serve the function of, have the capacity to, be capable of, have the ability to, be able to, etc.).

5. Verbs associated with structure of buildings (e.g. to construct, rest on, act as, excavate, support, drill, assemble, transmit, wire, etc.).

6. Numerals expressing quantity.

7. Decimal, fractions and percents (e.g. 2/3, 0.26, $13 / 8,78 \%$, etc.).

8. Verbalization of dimensions and scale (e.g. (1: 6) one-sixth).

9. Names of SI units to measure: noise level, mass, luminous flux, heat, distance, size, area, volume, etc. (e.g. kilogramme, millimeter, metre, lumen, joule, second, decibel, cubic metre, square metre, etc.).

10. Verbalisation of units of measurements (e.g. $\mathrm{kg} / \mathrm{m}^{3}$ - kilogramme per cubic metre, $\mathrm{km} / \mathrm{h}-$ kilometer per hour, etc.).

11. Expressions of variation and change (e.g. to vary between... and..., to range from ...to..., etc.).

12. Words of extremes and average: (e.g. max., min., average, etc.).

13. Ways of expressing relative quantities (e.g. 5 times as big as, more / less than, etc.).

14. Modification of comparative expressions (e.g. slightly bigger, considerably, bigger, much bigger, etc.).

15. Expressions of ratio (e.g. The ratio between the length and width of the room is 6 to 4, etc.).

This classification can be expanded by means of specific grammar constructions typical of technical English:

- high frequency of one-two-three and more component abbreviations (c (ceiling); $C$ (cold water); $C$ (Celsius); A.T. (air temperature); b.p. (base plate); r.s./w. (roof support/wall); A.E.S.C. (American
Engineering Standard Committee); A.S.C.E. (American Society of Civil Engineers) etc.);

- high frequency of nouns in the attribute functions (wall board, lear board, layer board, ridge board, barge board, verge board; box gutter, lear gutter; hammer beam, dragon beam, principal beam etc.);

- high frequency of grammar constructions with Participle I and Participle II (adjoining arches, birding beam, hanging gutter, colonnaded space, curved arch domed building, built-up beam, arcaded space, crossed strips, roofed structure, framed structure etc.);

- wide use of verbs denoting architectural and construction processes (to design, carry loads, transfer, resist, define, compensate, rotate, fix, distribute, extend, restrain, enclose, construct, lean, intersect, form, extend, bear, project etc.) [9].

A future architect or a builder should know and be able to use special statements necessary for presentation of his project. The most frequent among them are the following:

- statements of position: be + preposition + noun phrase (There is a+ noun phrase+ prepositional phrase) (e.g. The building is next to the residential district.);

- statements of function: noun phrase + have + noun phrase (e.g. The building has five flat external surfaces.);

- statements of property: noun phrase + be + adjective (e.g. Glass is transparent); noun phrase + have the property of + noun phrase (e.g. Steel has the property of high tensile strength);

- statements of shape: noun phrase + be + (shaped like + noun phrase/adjective + in shape/noun- shaped/ adjective) (e.g. the brick is shaped like a rectangular prism. the cross-section of a brick is rectangular in shape.);

- statements of dimension: noun phrase + to be (to have, measured in) + noun phrase (e.g. the volume of the ground floor is 123 cubic metres. the room has a crosssectional area of 34 square metres. the temperature of air is measured in degrees.);

- statements of scale: unit + represent + unit (e.g.: 7 $\mathrm{cm}$ represent $10 \mathrm{~km}, 1 \mathrm{~cm}$ represents 1000 metres, etc.);

- statements of comment on of graphic elements: noun phrase + verb (e.g. to show, demonstrate, etc.);

- statements with passive and modal verbs, their equivalents [5].

The model we develop includes 3 stages / modules. Within the first stage, students acquire the classification of building and architectural terms, learn to use special terms which composes the thesaurus of the future specialty and can be presented by the following groups [8]:

- types of buildings and rooms (e.g. government office, edifice, skyscraper, low-rise building, mid-rise building, high-rise, attic, crawl space, cellar, living room, break room, detached house, cottage, block of flats, crawl space, cellar, rest room, etc.);

- structures and parts of a building (e.g. structural element, member, unit, construction joints, subfloor, roof frame, span, bearing wall system, frame system, cornice, pier, column, capitals, abacus, architrave, frieze, entablature, colonnade, arcade, spandrel, 
basement, subbasement, masonry structure, framework, arched structure, vaulting shaft, etc.);

- building materials and properties (e.g. concrete, plywood, reinforced concrete, timber, sand, steel; combustible, permeable, transparent, corrosion resistant, a good conductor of heat, flexible, elastic, etc.);

- building maintenance (e.g. heating, airconditioning, sound insulation, ventilation, illumination, requirements for the building, etc.);

- basic building terms (e.g. stress, strength, compression, tension, lateral stability, depth, width, physical capacities, length, height, temperature, electricity, relative humidity, prevailing wind, lateral stability, etc.);

- nouns and adjectives describing shapes (e.g. triangular, rectangular, square, semi-circular, pyramidal, conical, cylindrical, etc.);

8) technical drawing terms (e.g. ground floor plan, elevation, section, cut-away view, front, back, sides of a building, closed plan, open plan, roof plan, site plan, area plan, section, cross section, longitudinal section, oblique section, drawing, exploded view, layout, etc.);

- types of lines and diagrams (e.g. object line, dashed line, dotted line center line, extension line; pie chart, flow chart, bar chart, etc.);

10) names of symbols ( e.g. () (parentheses); * (asterisk, star, splat, gear); . (full point, point, period, dot, spot); / (oblique stroke, oblique, slat, slash, forward slash); I (back slash); ^ (caret, hat, shark fin, circumflex); : (colon, two spot); ; (semicolon, semi); (hyphen); - (en-dash); _(underline, flat worm); < (less than, angle, left angle bracket, open angle bracket, left bracket); > (greater than, right angle, right angle bracket, close angle bracket, right bracket); \{\}, etc.). [9]

To master these multi-aspect and complex lexical material the following types of exercises can be recommended:

- Match the words with the definitions.

- Fill in the blanks in the sentences with the correct words from the word bank.

- Read the poster on worksite safety. Then, mark the statements as true $(\mathrm{T})$ or false $(\mathrm{F})$.

- Read the sentence pair. Choose where the words best fit the blanks.

- Fill in the gaps in the text using the information below.

- Study the plans of an Egyptian house shown on the drawing; match the letters with the names of the rooms and areas.

- Using the drawing, define what elements and parts of the building are marked by letters: roof, building site, wall, structure, foundation, floor, ceiling, window, mechanical system, door, room.

- Study the properties of materials. Match A and B. They are antonyms.

- Identify the types of construction with the drawings.

- Give the English equivalents to the Russian ones.

The second stage is devoted to acquisition of speech skills and habits in specified contexts connected with future specialty. We recommend the following exercises:
- Draw the lines: a straight line, bumpy curve, curve, solid line, broken line, dotted line, etc.

- Make the drawings of the shapes: square, circular, semi-circular, rectangular, triangular, cubic, hemispherical, prismatic, pyramidal, conical, cylindrical.

- Pronounce and write down the following: 2/3 ton, 1.75, 3/4km, .75km, $240 \mathrm{~km} / \mathrm{hr}$, 40h.p., etc.

- Study common and decimal fractions to present a scale and dimensions of an object (Table 1).

Table 1. Scale and dimensions of an object.

\begin{tabular}{|c|c|}
\hline Scale & Dimensions \\
\hline $1 / 2$ & A half, one half \\
\hline $1 / 3$ & A third, one third \\
\hline $1 / 4$ & A quarter, one quarter, a fourth, one fourth \\
\hline $1 / 10$ & A tenth, one tenth \\
\hline $1 / 100$ & A (one) hundredth \\
\hline $1 / 1000$ & A (one) thousandth \\
\hline $1 / 1234$ & $\begin{array}{l}\text { A (one) thousand two hundred and thirty- } \\
\text { fourth }\end{array}$ \\
\hline $3 / 4$ & three fourths, three quarters \\
\hline $2 \frac{1}{2}$ & two and a half \\
\hline $1253 / 4$ & $\begin{array}{l}\text { a (one) hundred and twenty-five and three- } \\
\text { fourths (three quarters) }\end{array}$ \\
\hline 0.1 & $\begin{array}{l}\text { O point one, nought point one, zero point one } \\
\text { point one }\end{array}$ \\
\hline 0.01 & $\begin{array}{c}\text { O point o one, nought point nought one, zero } \\
\text { point zero one }\end{array}$ \\
\hline .01 & point nought, one point zero one \\
\hline 0.25 & nought point two five \\
\hline .25 & point two five \\
\hline 2.35 & two point three five \\
\hline 45.67 & $\begin{array}{l}\text { four five point six seven, forty-five point six } \\
\text { seven }\end{array}$ \\
\hline 0.001 & O point o o one \\
\hline .001 & $\begin{array}{l}\text { nought point nought nought one, zero point } \\
\text { zero zero one, point nought nought one }\end{array}$ \\
\hline
\end{tabular}

The purpose of the third stage is to develop the general skills - reading, writing, listening and speaking for professional activity in intercultural communication: to give a presentation of an architectural project, to participate in a discussion, to give a reasoned explanation and defend one's point of view. The following tasks can be used for this purpose:

- Read the text and give your understanding of its main idea.

- Look at the drawing illustrating the location of the building and describe it.

- Act out the roles with a partner:

Student A. You are a contractor. Tell student B about a site layout, tasks to be fulfilled, the order of events.

Student B. You are a foreman. Tell student A about the plan for a site layout.

- Give a presentation of the suggested object.

- Study the explanatory note of the entertaining center. Suggest the structure of the presentation of the architectural project (Table 2).

- Study the table and make sentences as shown (see Table 3). 
Table 2. Structure of the presentation of the architectural project.

\begin{tabular}{|l|}
\hline \multicolumn{1}{|c|}{ CONTENTS } \\
\hline 1. Section 1. General part \\
\hline 2. Section 2. Architectural part \\
\hline 2.1. Layout \\
\hline 2.2. Spatial planning concepts \\
\hline 2.3. Constructional concepts \\
\hline 2.4. Engineering systems of the building \\
\hline 3. Section 3. Calculation and constructional part \\
\hline 4. Section 4. Bar chart of sequence of trades. \\
\hline 5. Section 5. Economic part \\
\hline
\end{tabular}

Table 3. The components of a building.

\begin{tabular}{|c|c|c|c|}
\hline Elements & $\begin{array}{c}\text { Compound } \\
\text { units }\end{array}$ & Units & Materials \\
\hline Roof & $\begin{array}{c}\text { roof structure } \\
\text { waterproof } \\
\text { covering }\end{array}$ & $\begin{array}{c}\text { joists and } \\
\text { slabs }\end{array}$ & $\begin{array}{c}\text { timber } \\
\text { wood } \\
\text { wool } \\
\text { asphalt }\end{array}$ \\
\hline Walls & cladding & $\begin{array}{c}\text { corrugated } \\
\text { sheets } \\
\text { beams and } \\
\text { stanchions }\end{array}$ & $\begin{array}{c}\text { steel } \\
\text { steel }\end{array}$ \\
\hline Floors & wearing & surface \\
tiles panels & $\begin{array}{c}\text { vinyl } \\
\text { precast } \\
\text { concrete }\end{array}$ \\
\hline Foundation & wooden & column bases & concrete \\
\hline
\end{tabular}

- Listen to the dialogue and complete the conversation.

- Listen to a conversation between a contractor and an employee. Choose the correct answers.

- Listen and read the website from a construction company about excavation. Answer the questions.

- Use the information about different types of foundation. Write Pros and Cons as for a shallow or deep foundation.

- Imagine that you are applying for a new building company as a foreman. Compose your $C V$.

- Imagine that there is a plan to construct a new office building in your neighborhood. Would you favour or oppose building the new edifice? Use specific examples and reasons to suppose your opinion.

Thus mastering of foreign language proficiency at the architectural university is based on the professionally oriented information and lexico-grammatical specificity of technical English. The offered model of teaching English promotes development of foreign language literacy and fundamentals of basic skills and habits in communication. The system of exercises of lexical, grammatical and syntactic levels gives possible ways to improve the educational potential of the foreign language at the architectural university due to deployment of modern approaches and techniques in intercultural communication within international conferences, seminars, trainings or lectures.

\section{References}

1. T.N. Astafurova. Linguistic aspects of intercultural business communication (Volgograd: VolGU, 1997)
2. T.N. Astafurova, N.A. Vishnevetskaya, Kozlova O.P., O.N. Romanova, E.V. Surkova, The formation of the foreign commincative competence of students in non-language schools. Monograph (Volgograd, 2017)

3. N.N. Bobyreva, Procedia. Social and Behavioral Sciences 182 (2015)

4. I.G. Budagyan, Vishnevetskaya N.A., Romanova O. N. The Specific translation of the architectural texts. Business. Education. Law, 4 (Volgograd, 2015)

5. J. Cumming, Architecture and Building (Longman, 2004)

6. V. Evans, J. Dooley, Building Construction (Express Publishing, 2012)

7. O.P. Kozlova, A.A. Petiy, Journal «Concept» 19 (2017)

8. O.P. Kornienko, A.A. Petiy, Vestnik of Volgograd State Pedagogical University 5(6) (2012)

9. Kornienko O.P. The formation of the foreign engineering competence for specialists (in terms of architectural-building specialities), extended abstract of cand. dissertation (Pyatigorsk, 2009)

10. Romanova O.N. Internet-vestnik VolGASU 1(31) (2014) 